\title{
Using Technology to help the Citizen Enrollment
}

\author{
Marcos Clayton Pessoa, Joaquim Celestino Júnior, Sandra Maciel Barreto, \\ and José Carvalho Filho (Júnior) \\ Instituto do Software do Ceará - INSOFT, mclayton@insoft.softex.br \\ Av. Santos Dumont, 1180 - Aldeota, 60150-160 Fortaleza, Ceara, Brasil, \\ http://www.insoft.softex.br
}

Abstract: TECHNOLOGY FOR HUMANIZATION was planned and accomplished
during 6 months by the Institute of Software of Ceara - INSOFT - for the
Secretary of Basic Education of Ceara - SEDUC - in 2000 and 2001 . Its
objective is to enhance the attendance to the citizen, in other words, to the
parents willing to enroll their children in any school of the State Net in the
capital of Ceará. The challenge of serving a public that had been facing very
long lines for 10 years searching a vacancy for their children, made us believe
that the technology was connected to a wish: offering a humanized attendance.

Recognizing a mistake

“...it is crystal clear to recognize that the enrollment time in the public schools was quite different from what happened these last few years. The atmosphere was quiet with a handful of difficulties that were promptly solved. The media coverage itself confirmed that (Fco. Bilas, Diário do Nordeste Newspaper, February $04^{\text {th }}, 2000$ ).

Recognizing a mistake... That was the judgment of journalist Francisco Bilas in relation to the project TECHNOLOGY FOR HUMANIZATION that was planned and accomplished during 6 months by the Institute of Software of Ceará - INSOFT - for the Secretary of Basic Education of Ceará - SEDUC - in 2000 and 2001. Its objective is to enhance the attendance to the citizen, in other words, to the parents willing to enroll their children in any school of the State Net in the capital of Ceará. 
The challenge of serving a public that had been facing very long lines for 10 years searching a vacancy for their children, made us believe that the technology was connected to a wish: offering a humanized attendance.

This is not only a project, it is a tool that put technologies altogether to give back to the citizen time and respect.

The innovative aspect of the whole project is made of the integration of technologies and human actions that benefit the citizen.

In order to guarantee the promptness and dignity in the attendance to all those who go to the Public Schools and put in practice the Management Accomplishment Plan - "PIG", the General Plan of the Project - "PGP" and the Detailed Management Plans - "PGD", following the cycle of planning: Planning, action, mensuration, evaluation and review - the first step was the accomplishment of a research.

THE RESEARCH "in locu" was accomplished in 202 schools of the State Public Net was made of: methodology, researcher selection, division and subdivision of the administrative areas, researcher kit, assistance, return to school, data collection, review, information management and graphic generation. From the last one we got: 1) General File of the School; 2) InfraStructure; 3) Equipment, a diagnosis of the real conditions holding: parabolic antenna, projector, software, a stereo, stabilizer, a small frige, printer, information science laboratory, computers, fax modem board, net board, nobreak, screen, television, transcoder and video cassette recorder. We underline from the data: stereo - $16 \%$ no $x 84 \%$ yes, computers $-10 \%$ no $x$ $90 \%$ yes, printer $-13 \%$ no $\times 87 \%$ yes and information science laboratory $60 \%$ no $\times 40 \%$ yes. Also, the research presented quantitative data and demand (student $x$ grade) by administrative area and measured the degree of satisfaction of the directors in relation to the project suggested by the "INSOFT", where 73\% judged the project as good and very good.

From this point, the information management measured, for a group of 202 schools, the 187 enrollment posts, set in 20 support centers, the need of personnel by school, the need of equipment and logic cable net by school and the final cost of the project, that saved $900 \%$ in relation to other proposals (the distinction was the RESEARCH).

The Project also counted on the Enrollment Engineering, that made the enrollment schedule allowing the priority to children between $7-14$ years by teaching subject - in specific days, setting the beginning of the process on Tuesdays, preventing this way long lines.

Bearing in mind the initial planning of INSOFT, the cycle of planning now defines the philosophies, management policies and routes of the project, in a combined action SEDUC/INSOFT, defining the PIG, counting on a democrative participation of the delegates of the directors by administrative 
area, as points Paul Campbell, "running a business in a participative way is a matter of style and not of tools"(page 113).

The structure of the project followed this organization: SEDUC, Enrollment Commission SEDUC/INSOFT, INSOFT, Support Center and School, each of these Institutions had their own organizational structures.

Besides, the will of the State Government to accomplish a humanized enrollment assured that: 1. It could be accomplished in the School; and 2. The students of the Public School Net could take the control working as operators in the process, taking into account that $40 \%$ of the Schools already had information science laboratory and $90 \%$ had at least one computer.

Thus, the General Plan of the Project was settled in seven phases, sometimes occurring at the same time, sometimes not: 1. Research "in locu"; 2. Generation SEDUC/INSOFT; 3. Assistance; 4. software Development; 5. Diffusion; 6. Accomplishment; and 7. Conclusion.

In the GENERATION of the design of the software, trainings and diffusion to the whole community, the staffs used a number of technologies of knowledge: administration, marketing, psychology, pedagogy, information science, etc.

The ASSISTANCE followed two rules: decentralization and knowledge. Twenty supervisors were trained in a area of $336 \mathrm{~km} 2$ running their own Support Center or Administrative Area and transmitting the knowledge about: 1. Structure and process of Enrollment; 2. Information Science; and 3. Citizenship, where the philosophy of the project was inserted through contents such as: attendance, communication, individual and collective respect and special cases. The 20 supervisors trained and managed through the "PGD", 1512 professionals holding directors, secretaries, supporters and scholars, confirming the thought of Roger von Oech who stated that "when we contract someone, not only the intelligence or efficiency is considered. For us, the characteristics, the people are enthusiastic (enthousiasmos - from Grek - the God within) these are the ones who produce new ideas"(page 111).

For the DEVELOPMENT OF THE SOFTWARE, in a record time, besides the accomplishment of the enrollment of transferred, senior and freshman students, demands were connected to the system, making the process dynamic with mechanisms that allowed the operator with a single click to send data to the provider INSOFT, which automatically updated them in the home page. Also, the effort of the staff, therefore, it is necessary that everything works in perfect harmony - the net, the data center and the applications. It has to do with "performance"(how fast the processing occurs), back-up and information recuperation, fine tuning of the data center, configuration of the equipment, access authorizations and several other technical aspects that have to be considered by the "staff", experts whose job 
is to "balance the atmosphere" so that the user realizes a safe, fast and reliable system"(page 96).

The educative, informative and final DIFFUSION, as well as the development of the software, were crucial to the success of the project. All communication efforts strategically employed in the process had as a result unique facts such as: 1 . Diffusion in the newspaper (double page) of the official enrollment schedule, with 187 enrollments posts described by administrative area, address and number of vacancies available by subject of teaching; 2. Fast information to the society; 3 . Positive repercussion in the electronic media and press.

The sixth phase, ACCOMPLISHMENT, took one month - enrollment period, that is, after the accomplishment of the research, with the guide plans defined, personnel trained, staffs formed, software developed, the system installed and information spread. It is time to do the job!

The available resources for such a mission were: information, maps, telephone, cellular, fax, trunk radios, call center, computers, software, access to Internet, homepage, cars and administrative flexibility.

The communication via net work to send information as well as to search information.

The communication worked every 4 hours sending information, in the following order: access dialed from School to the provider of INSOFT and then to the web. In case any problem occurred with the transmission in the School, the alternative was: do the back-up from the School to the Support Center, which had a information science laboratory, accessing the provider INSOFT, sending the data which were automatically updated in the Internet via home page.

Besides the home page, other means were used to search information. The trunck radio played an important role with distinct channels for each administrative area, making the negotiations easier for the supervisors and directors in the placement of the students near their homes according to the law.

Daily, vacancy reports of each School were launched by region and in general. Besides the updated status that was the route for the SEDUC in terms of measures to be taken such as: construction of new rooms, rent of buildings, refurbishments of rooms and subdued demand.

During the project, physical, material and human ressources were used all over Fortaleza, the State Capital, in an operation of citizenship.

The physical structure of many institutions were used: SEDUC, the Regional Center of Education Development - CREDE - , 21,70\% of the the area of INSOFT , 187 schools or enrollment posts and 20 support centers with information science laboratories that belonged to the schools. 
The material structure used, which most of it belongs to the Schools nowadays, received a preventive e corrective maintenance, trunck radios, call centers, computers, upgrades (extra or new parts), printers and provider, which recorded 5197 accesses for transmission data in the enrollment period.

The human structure was made of 1512 professionals from different areas and institutions, taking into account the philosophy pointed by the anthropologist, writer, educator and business consultant, Angeles Arrien that, "every individual is an original medicine"(page 67). The SEDUC worked side by side with the enrollment committee, executive enrollment commission, technological support center and public relations. The CREDE 21 made the GT of School Management Support and the GT of Planning and Statistics perform intensively. The INSOFT counted on General Director, general coordinator, financial coordinator, sub-coordinators, public relations assistant, supervisors, technicians, supporters, drivers, call center operators and Administrative Support. Also, the INSOFT counted on the directors, secretaries, supporters and scholars from the Schools.

The TECHNOLOGY FOR HUMANIZATION project benefited the whole community and 45581 parents that were promptly attended and 620 students who worked as operators, receiving assistance and a scholar. In an indirect way, the directors, secretaries, supporters and members of the staff were also benefited.

The project was planned during a few months and accomplished in January. February was chosen to do the final back-up of all data from the Schools and consolidation in only one base with more than 310000 files. Everything finished the general report was delivered and the database consolidated.

The results represent much more than ordinary figures because we all dealt with culture, consciousness and new concepts such as: 1) the accomplishment of the enrollment at the School itself; 2) the research made a deep diagnosis of the Schools; 3) all Schools have a telephone line (75 of them did not have one); 4) All Schools have access to Internet (which is still working), some of them received a fax modem board and net board; 5) fast service with accessible information and access to it; 6) 1512 professionals trained in Enrollment Structure, Information Science and Citizenship; 7) 620 students received scholars, a social benefit with the focus on citizenship; 8) Hard working Directors who had their complaints listened by the State Government; 9) Computerized Schools. All Schools received upgrades; 10) Satisfied Community, with the quality of attendance, the use of technology and consideration in relation to time and the citizen; 11) Positive Repercussion in the electronic media and press; 12) $900 \%$ save in relation to other proposals. Finantial cost of $\mathrm{R} \$ 548.000,00$ (Five hundred and forty 
eight thousand reais); 13) 45.581 new enrollments and 14) Enrollment Engineering which benefit the elderly people.

The reproduction of the project is totally possible taking into account the technological and financial aspects. The most important tool is the will.

The technology integration requires research, methodology, definition, hardware and software which already exist and fit to other conditions.

The financial aspect will be defined from real conditions. The project itself might be transferred through technology, knowledge and/or just through the INSOFT staff (who is in charge of the methodology TECHNOLOGY FOR HUMANIZATION). It was crystal clear that the financial cost of $\mathrm{R} \$ 548000,00$ (Five hundred and forty eight thousand reais) was low before the benefits and in comparison with other proposals. The project was accomplished with a reduction of $900 \%$ in the value and a new local solution was settled.

The atmosphere of the Enrollment time in the State Capital of Ceará is clearly expressed in a phrase naturally pronounced among coordinators, directors, supervisors and the highest hierarchy of the project: GO FOR IT!. It was a magical time underlined by teamwork in the meetings all night long. There was no room for discouragement. The battle cry was: Time! - We've got none!// Problem! - Solutions!// Solutions! - The best!// The best! Success!

The success that was reached is a sign of encounter, respect and intellectual ability which was amplified in the next motivated by the same objective: HUMANIZATION.

\section{CITIZEN ENROLLMENT}

The SEDUC (Secretary of Education) invited the Institute of Software of Ceará (INSOFT) to accomplish the Enrollment in 2001 due to the success in 2000.

In order to benefit the population the INSOFT decided to invest in a research again. It is necessary to update the new reality of the Schools and specially the student data center. Thus, four groups of INSOFT technicians went to the 209 Schools of Fortaleza:

The first group with the objective of updating the data center checked the student status (present grade, transferred students and students who had quit) along with the School secretary's office personnel.;

The second group went to the Schools operating a GPS in order to locate them precisely. Then a application was created in the INTERNET to make the location easier to the citizen. 
The third group, made of civil construction technicians, had as the principal objective to update the data about the physical aspects. They measured the land and the rooms and designed the drafts as a reference.

The fourth group of Information Science technicians' accomplised a general evaluation of all equipment of the School making UPGADE and fixing machines. After this procedure, the Schools could count on the following minimum configuration: K6 500Mhz, a 32Mb RAM memory, a $6 \mathrm{~GB} \mathrm{HD}$ with soundboard and a $56 \mathrm{~K}$ fax modem board and Internet connection through INSOFT provider.

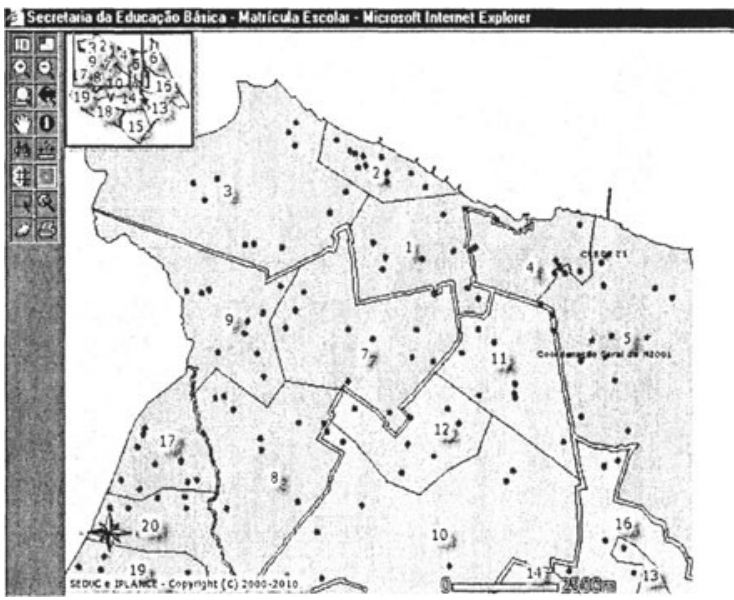

Figure 1: Fortaleza Map with schools located by GPS

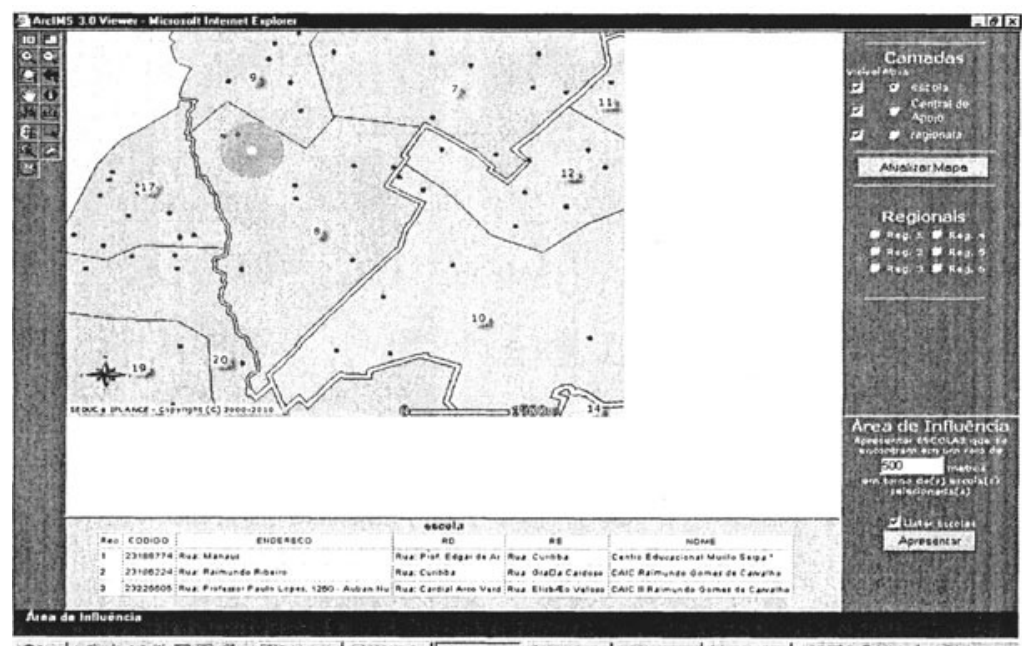

Figure 2: Search Function of the internet aplication 
The Secretary of Education accomplished the replacement and automatic enrollment of the students according to the data research, preventing four hundred thousand students to go to the Schools to do that.

In addition the Secretary of Education of Fortaleza also informed its student data and preferred Schools preventing the students to go to School to enroll themselves.

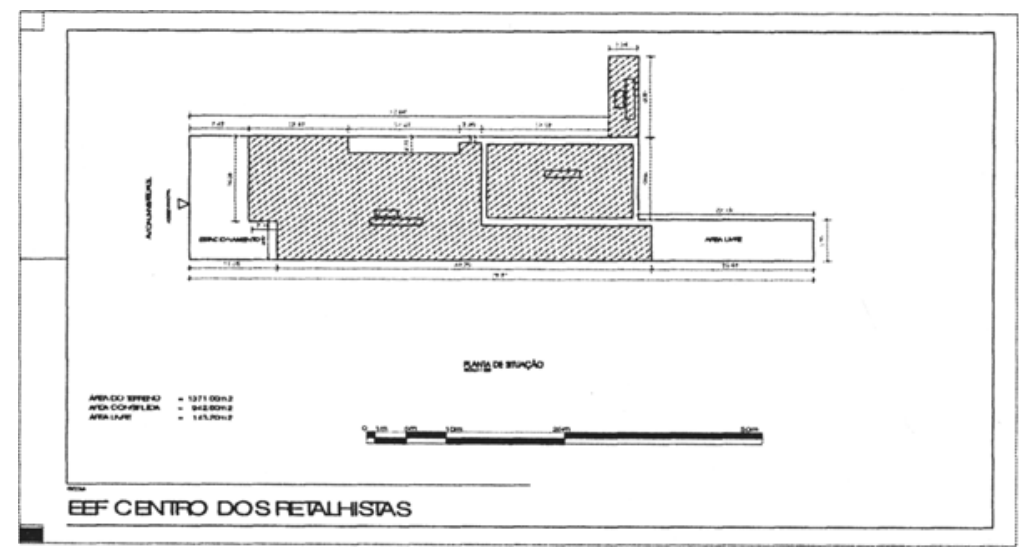

Figure 3: civil construction drafts

The Secretary of Education accomplished the replacement and automatic enrollment of the students according to the data research, preventing four hundred thousand students to go to the Schools to do that.

In addition the Secretary of Education of Fortaleza also informed its student data and preferred Schools preventing the students to go to School to enroll themselves.

In January the freshman students enrolled themselves. The State School Net offered 99332 vacancies but deserved only 45 503: 29907 in the Elementary School and 17.674 in High School.

We would like to underline that a great quantity of Elementary School students came from the City School Net who were recorded automatically.

A specific Enrollment Site was developed in order to have a fast access to information:

$\sqrt{ }$ Enrollment Process

$\sqrt{ }$ Enrollment Posts

$\sqrt{ }$ Enrollment Schedule

$\sqrt{ }$ Map of Fortaleza with city located through GPS

$\sqrt{ }$ Vacancy and Demand Report - updated every 4 hours 

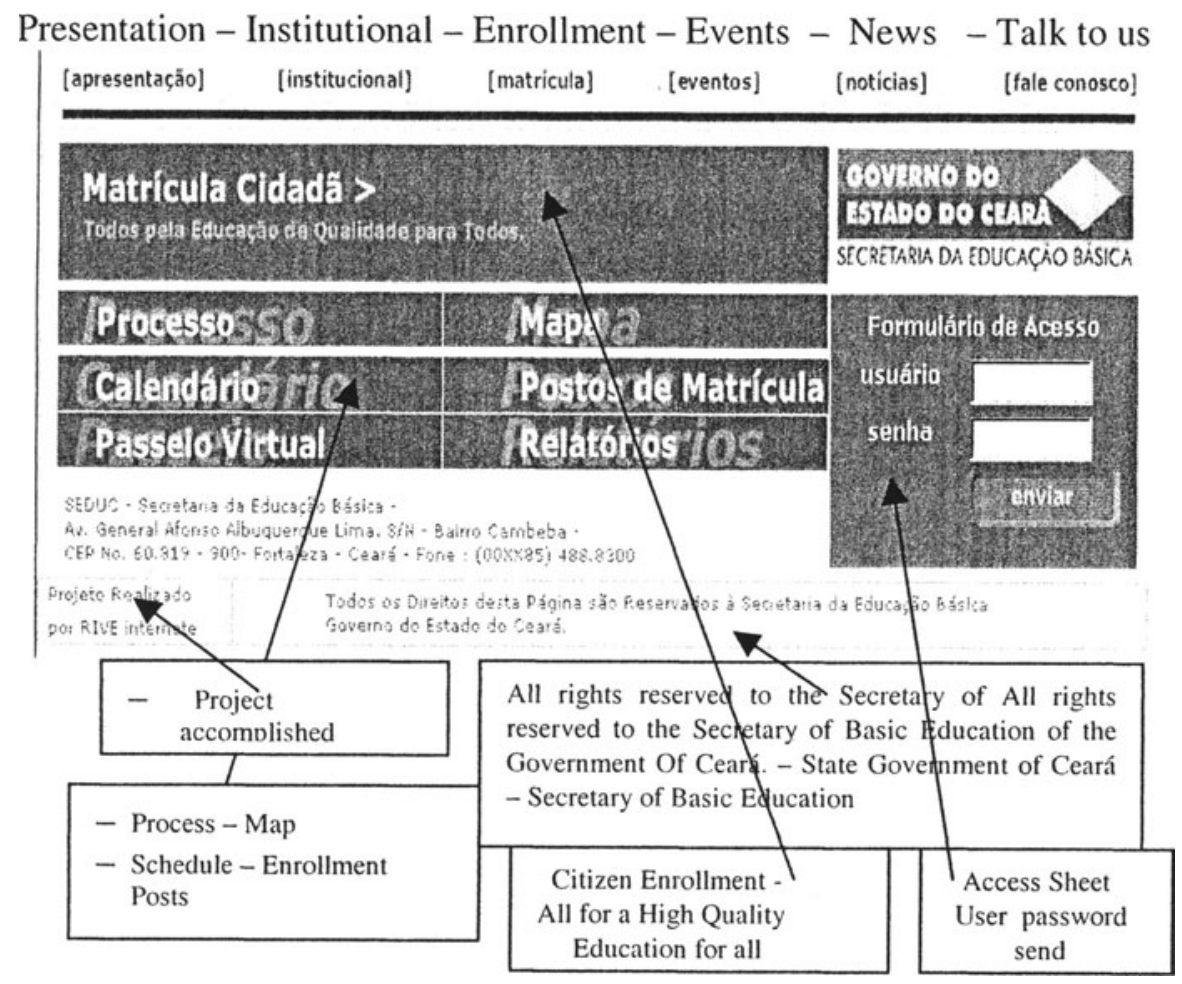

Figure 4: Web Page

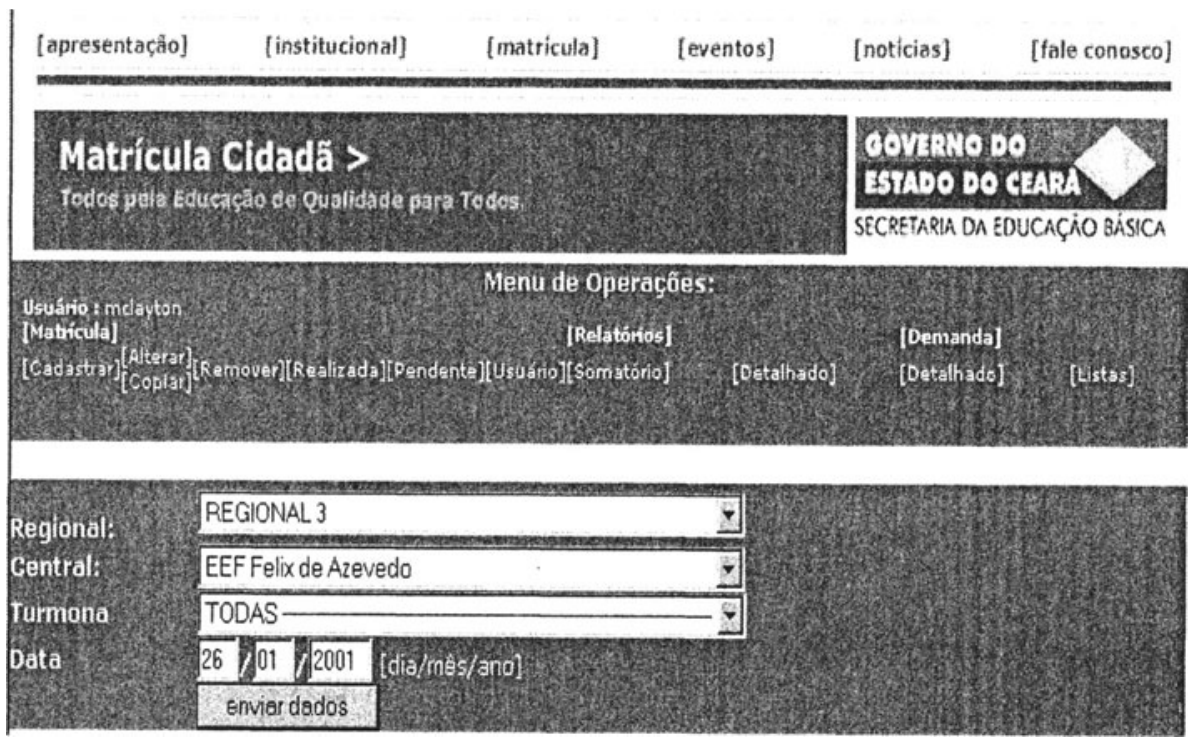

Figure 5: Search of vacancy in the Web page 
1935 professionals worked in the Enrollment Process as a whole, underlining:

- 190 Directors

- 190 Secretaries

- 205 Secretary of Education clerks

- 423 students ( typists)

- 804 Supporters ( Schools clerks and people of the community)

- General Coordination

- 3 Sub-Coordinations (Information Science, Operations and Financial)

- 20 Supervisors

- 26 Technicians

- 24 Supporters

- 20 Drivers

- 03 Technicians of the Information Science provider

- 02 Technicians in the accomplishment of the home page

1812 people were trained during 25 hours in the following contents:

- Windows

- Word

- Excel

- PowerPoint

- Management Software

- Citizenship

The methodology of training as well as the instructors belong to INSOFT, that accomplished the trainings in the information science laboratories of the Schools of the State Net.

Moreover, the 423 students received a $\mathrm{R} \$ 150,00$ scholar (Brazilian minimum monthly wage) and a 42 hour training.

The Enrollment Phone Service worked from December $26^{\text {th }}$ to January $26^{\text {th }}$ and answered 1983 calls. 


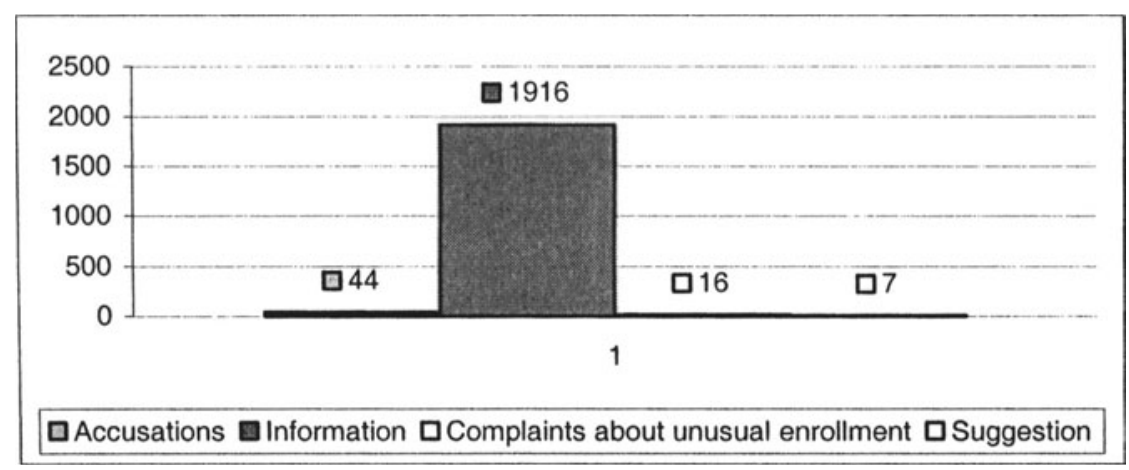

Graphic 1: Enrollment Phone Service - Kinks of request

\section{Guide}

Information that is not in the mark

Necessary papers to enrollment

Enrollment attendance time in the School

Location of the School

No vacancies in the desired School

Operator informs the Schools

Other information

Surroundings of Schools and Reference Points

Quantity of existing vacancies in the School

Check remaining vacancies
Number of events

102

186

39

647

67

94

233

190

355

3

1916

Table 1: Enrollment Phone Service - Kinks of request

\section{REFERENCES:}

ARRIEN, Angeles: $\mathrm{O}$ caminho quadruplo: trilhando os caminhos do guerreiro, do mestre, do curador e do visionário / Angeles Arrien; tradução Eleny C. Heller - São Paulo: Agora, 1997. ISBN 85-7183-520-9

DINSMORE, Paul Campbell: Gerência de programas e projetos / Paul Campbell Dinsmore. São Paulo: Pini, $1992 \quad 92.0470$ CDD 658.404

LOZINSKY, Sérgi: Software: tecnologia do negócio: em busca de benefícios e de sucesso na implantação de pacotes de software integrados / Sérgio Lozinsky. Rio de Janeiro: Imago Ed., 1996 . ISBN 85-312-0504-2

$O E C H$, Roger: Um "toc" na cuca: técnicas para quem quer Ter mais criatividade na vida / Roger von Oech; São Paulo: Cultura Editores Associados, 1995. ISBN 85-8513-02-4 POPCORN, Faith: $\mathrm{O}$ relatório Popcorn: centenas de idéias novos produtos, empreendimentos e novos mercados / Faith Popcorn; tradução Outras Palavras Consultoria Linguística e Serviços de Informática. - Rio de Janeiro: Campos, 1994. ISBN 85-7001-790-1 